Arhe XVI, 32/2019

UDK 111.852

008

DOI https://doi.org/10.19090/arhe.2019.32.141-167

Originalni naučni rad

Original Scientific Article

\author{
KOSTAS THEOLOGOU ${ }^{1}$ \\ National Technical University of Athens, Greece \\ YOULI RAPTI ${ }^{2}$ \\ National Technical University of Athens, Greece \\ PETER FETTNER ${ }^{3}$ \\ Johns Hopkins University School of Advanced International \\ Studies, Washington D. C., USA \\ YOULI PAPAIOANNOU ${ }^{4}$ \\ National Technical University of Athens, Greece
}

\title{
ART AND COMMUNICATION AS A NOVEL EXPERIENCE IN MODERN CULTURE
}

\begin{abstract}
In this paper we discuss the deadlocks of defining art in modern culture. The lack of criteria and modernism revisited are of crucial issue in this account. The theoretical mainframe of our approach is founded on the Frankfurt School thinkers (Max Horkheimer, Theodor Adorno, Walter Benjamin), and of course Jürgen Habermas. This theoretical apparatus also draws on contemporary accounts given by Sorbonne Professor Marc Jimenez and art critic John A. Walker. ${ }^{5}$ The paper discusses whether fine art may survive, in what forms - and to what purpose - in an age of mass media and in conditions of rapid networked communication. The paper sets off from the critical role radical art plays in today's divided yet global world and on the continuing debates between high art and low culture, but reflects on the interaction between art, media and technology.
\end{abstract}

\footnotetext{
${ }^{1}$ Author's e-mail address: cstheol@central.ntua.gr

${ }^{2}$ Author's e-mail address: yrapti@central.ntua.gr

3 Author's e-mail address: pfettner@mail.com

${ }^{4}$ Author's e-mail address: youlipa@gmail.com

5 Marc Jimenez, Qu'est-ce que l'esthétique, Paris: Gallimard, 1997; John A. Walker, Art in the Age of Mass Media, London: Pluto, 2001.
} 
To support our argument we suggest Body Art and other web/digital and technological applications in art, and the cyber-art currently being produced for the internet. The paper acknowledges the numerous interactions between art and culture in a postmodern pluralistic world, and draws from the vast range of contemporary works of art to illustrate and to criticize theoretical points. The true test of theory in aesthetics is their application to particular cases. When a theory shows limitations in such an application, we gain clues as to what theoretical adjustments or innovations are called for to accommodate today's works.

The introductory part of the essay comprehensively surveys recent debates on works of art, mass culture and society, and their socio-philosophical significance. The main discussion refers to the work of Walter Benjamin and Jürgen Habermas, aptly commented on by Marc Jimenez; ${ }^{6}$ after exploring the complex relationships between culture and art as it's reflected in that work, the argument provides an account of the 1980s political turn in aesthetics and explicates the impact of new communication technologies in modern culture. The narration is enhanced by specific examples of works of art in the era of mass media, web and digital culture, and underlines both the styles' pluralism and the variety of parameters affecting the interaction between art and mass media communication. Critical findings and suggestions for further research conclude the paper.

Keywords: art, technology applications, mass-culture, experience

\section{BRIEF HISTORICAL SURVEY OF THE DEBATE ON ART WORKS}

Since our way of seeing things is literally our way of living, the process of communication is in fact the process of community: the sharing of common meanings and thence common activities and purposes; the distribution, reception and interpretation of new meanings, leading to tensions, achievements, growth and change. ${ }^{7}$ The relationship between fine art and popular culture only became the subject of widespread debate relatively recently. In the interwar period early cultural critics, like Wyndham Lewis, ${ }^{8}$ Frank Raymond Leavis, ${ }^{9}$ and José

\footnotetext{
${ }^{6}$ Jimenez, Ibid.

7 Raymond Williams, Culture and Society 1780-1950, Garden City, NY: Doubleday Anchor Books, 1960.

8 Lewis, Wyndham, Men without Art, London: Cassell, 1934 and Lewis, Wyndham, The Human Age. Book 2: Monstre Gai. Book 3: Malign Fiesta (ill. M. Ayrton), London: Methuen, 1955.
} 
Ortega y Gasset, ${ }^{10}$ took up the over a century-old concern for the dangers of the cultural democratization process, but they all were intellectuals with a limited audience. In the 30's the Chicago School geographers and sociologists Robert Ezra Park ${ }^{11}$ and Herbert Blumer ${ }^{12}$ conducted the first empirical studies of mass culture. But in the 1940's and 50's the Frankfurt School's group of Walter Benjamin, ${ }^{13}$ Theodor Adorno, ${ }^{14}$ Max Horkheimer, ${ }^{15}$ and Herbert Marcuse ${ }^{16}$ produced an analysis relating mass

${ }^{9}$ Frank Raymond Leavis, Mass Civilisation and Minority Culture. Cambridge: CUP, 1930; Leavis, Frank Raymond, Denys Thompson, Culture and Environment: The Training of Critical Awareness, London: Chatto \& Windus, 1933; Leavis, Frank Raymond, The Great Tradition George Eliot, Henry James, Joseph Conrad, London: Chatto \& Windus, 1948.

${ }^{10}$ José Ortega y Gasset, The Dehumanization of Art, and Other Writings on Art and Culture, transl. H. Weyl, Garden City, N.Y.: Doubleday Anchor Books, 1956; José Ortega y Gasset, The Revolt of the Masses, transl. authorized, London: Allen \& Unwin, 1961.

${ }^{11}$ Robert Ezra Park, "Cultural Conflict and the Marginal Man" (Introduction), in: The Marginal Man. A Study in Personality and Culture Conflict, edited by Everett V. Stonequist, New York: Charles Scribner's Sons, 1937, xiii-xviii; Robert Ezra Park, C. W. M Hart, Talcott Parsons et al., Essays in Sociology. Toronto: University of Toronto Press, 1940; Robert Ezra Park, Race and Culture, Glencoe Ill: The Free Press, 1950.

12 Herbert Blumer, Symbolic Interactionism: Perspective and Method. Englewood Cliffs, NJ: Prentice-Hall, 1969; Herbert Blumer, "Social Problems as Collective Behavior", Social Problems n. 18 (1971): 298-306.

13 Walter Benjamin, Das Kunstwerk im Zeitalter seiner technischen Reproduzierbarkeit [L'oeuvre d'art à l'époque de sa reproduction mécanisée, transl. P: Klossowski, 1936, 42-68, accessed May 25, 2014) http://ia600805.us.archive.org/2/items/ZeitschriftFrSozialforschung5.Jg/Zeitschri ftFrSozialforschung51936.pdf.

${ }^{14}$ Theodor Adorno, Minima Moralia, Reflexionen aus dem beschädigten Leben. Frankfurt am Main: Suhrkamp, 1951 /2005, Minima Moralia, Reflexions from Damaged Life, transl. D. Redmond, accessed May 25, 2014, http://monkeybear.info/MinimaMoralia_Full.pdf.

15 Max Horkheimer \& Theodor W., Adorno "Kulturindustrie, Aufklärung als Massenbetrug", in: Dialektik der Aufklärung. Philosophische Fragmente, Frankfurt am Main: Fischer, 2012/1947, 148-196.

16 Herbert Marcuse, "The Affirmative Character of Culture", in: Herbert Marcuse: Art and Liberation, Douglas Kellner (ed.) vol. 4, London and N.Y.: Routledge, 1932/2007, 82-112. 
culture to mass society and ultimately totalitarianism, and the debate on popular culture thereby became commonplace in western culture academic circles. It was the first time that a critique of mass culture was produced from a radical and not a conservative point of view, demonstrating the crucial significance of the media in forming social consciousness and underlining the limits of social change within consumerist capitalism. Like his successor at the Frankfurt School, Habermas, Adorno is interested in the historical question of how the artworld developed its relative autonomy in modern times.

\section{ART - CULTURE - AUDIENCE: A COMPLEXITY IN CRITIQUE AND AESTHETICS}

During the last four decades the evolution of art has taken the form of rich events and regressions; the emergence of vanguards is followed by their decline and wane, under conditions of an exponential growth of the art market and cultural consumption as a constituent of a life style. Consumption of art has resulted in a crisis, a mutual declaration of war between modern and contemporary art, an invasion of technology in art, and an old fashioned nostalgia for all forgotten 'traditional' values. These developments were accompanied by both a disorientated critique of art and a feeble aesthetic critical approach to the work of art. After 1980 the public ceased to perceive an artwork in the same way as in the past, and the deficient aesthetic critique was due, firstly, to the complexity of techniques, and secondly, to the failure of aesthetics to comprehend and interpret the new artwork. Art theorists seem unable to catch up and conceptualize all of the new practices and technical evolutions in art production; aesthetics stands uncomfortable in front of the novel artwork. ${ }^{17}$ These developments tend to deflate any optimism about formulating a general art theory in our times.

The problem is located in the role of public and private cultural institutions, as well as in the ever-growing role of new media in producing, reproducing and commercializing works of art. The new

\footnotetext{
${ }^{17}$ Jimenez, Qu'est-ce que l'esthétique, 11-13.
} 
technology affects the status of creativity and originality in contemporary art and society; works of art are not required to be pristine or 'unspoiled', not expected to authentically disclose the subjectivity of the individual artist as they were under Modernism. But even before the internet and digital art, the new roles of cultural institutions, mass media, and mass communication had significantly altered the interaction between art and society; Walter Benjamin had prominently pointed that out. Aesthetic experience is affected, if not essentially transformed, by novel modes of interacting with space and time, with places and their history; touristic and virtual tours in museums, galleries and modern art installations through PC or iPad palm screens, and $360^{\circ}$ digital representations are not convincingly explained by older concepts of the intensity of the genuine "aesthetic experience" per se and its educative or inspirational roles in modern everyday life.

\subsection{The 1980 turn: modernism revisited}

Since the late 70's Modernism faced a post-modern era with features like the loss of master-narratives, the "end of history," the advent of irony in opposition to Modernist seriousness and sincerity, and claims about a deep rupture between values of the past and values of the present or the future. ${ }^{18}$ Art criticism and philosophical aesthetics faced the difficulties not only of inventing appropriate criteria for judging the quality of an artwork, but also of redefining what counts as an artwork at all. Today's aesthetics and art criticism must respond to the emerging issues posed by present artistic production, and this is impossible to the extent that aesthetics maintains an uncritical relation with its philosophical origins. ${ }^{19}$

Art is subject to economic and cultural imperatives and trends; it is in a permanent interaction with technology and information society that potentially allows for impulsive action on the part of almost any

${ }^{18}$ Jean-François Lyotard, La condition postmoderne: rapport sur le savoir, Paris : Minuit, 1979.

${ }^{19}$ Jimenez, Qu'est-ce que l'esthétique, 18. 
individual, hence posing questions about the pragmatic state of art and its social role. The social status of an art 'accessible' to all is related to the quality of democracy, i.e. the democratization processes of a regime. The democratization of culture and the financial funding provided by the state to the initiatives of various projects in the modern art sphere also change the way public audiences perceive and understand art. $^{20}$ Current developments in art seem inconsistent with the ideas of Theodor Adorno ${ }^{21}$ in fact, counter to his point of view, art is no longer submitted to the absolute imperatives and trends of avant-garde -often called radical- modernity. ${ }^{22}$ Despite these historical limitations, Adorno's point of view still determines our reflections on aesthetic phenomena and art products. The relation between art and politics, which was of crucial importance during the 70 's, has been radically transformed in the environment of today's global, post-industrial society. In the 70's, the task was to bring up-to-date the crucial significance of the avant-garde artists in the early twentieth century; this perhaps also explains the persistence of a stylistic pluralism in the struggle against the commercialization of art in everyday life. Aesthetics and philosophy of art offer their theoretical protection to artists who seek to subvert the official policies and institutions governing cultural activity. Theory of art takes on a new importance in the face of the unprecedented development of a global culture. But both art criticism and the art-world audience are hampered in reforming the theory of art by modernity revisited, which calls for a reversion to classical values, denounces the concept 'everything can be art' and, last but not least, decries the demise of

\footnotetext{
${ }^{20}$ Jimenez, Ibid; Walker, Art in the Age of Mass Media.

${ }^{21}$ Adorno, Minima Moralia; Theodor Adorno Asthetische Theorie, Frankfurt am Main: Suhrkamp, Aesthetic Theory, transl. R. Hulot-Kentor, New York-London: Continuum, 1970/1997.

${ }^{22}$ Youli Rapti, "The end of autonomy in modern art", in: Humanities and Social Sciences in NTUA: fertile ramifications, I. Milios - K. Theologou (eds.) Athens: NTUA publications [in Greek], 2011, 272-278.
} 
criteria in art. $^{23}$ This reactionary development has political and ideological dimensions that were connected with the political developments of the beginning of the 80 's.

\subsection{The significance of communication}

We draw attention to the fact that Adorno's overvaluing of subjective experience is open to question, and that his bold refusal to 'come to terms' with the mass cultural industry ignites criticism by philosophers who, nevertheless, still assent to his theory in its broad outlines. They believe that the aesthetic experience of both traditional and modern art is so powerful and robust that it can resist the leveling tendencies of the digital image, popular culture, and a commercialized art-world. Because communication is the inescapable constituent of everyday life and culture, the theory of Jürgen Habermas must be taken into account in our contemplation of contemporary aesthetics, art and technology. His ideas provide a theoretical legitimization of the claim that digital Media can increase the dissemination of works of art to the public and thus enhance the renewal of the aesthetic experience. In contrast to Adorno, Habermas' sense of a possible renewal is juxtaposed to the impoverishment or the atrophy of aesthetic experience that troubled his more pessimistic colleague. ${ }^{24}$

Habermas is critical of the view of the culture industry expressed in both Max Horkheimer and Theodor Adorno. ${ }^{25} \mathrm{He}$ doesn't share the concept that the dominance of the economic system over the art-world, which takes the form of commodification, transforms aesthetic pleasure into mere entertainment or consumption. ${ }^{26}$ According to Habermas, cultural consumption doesn't provide balance to the 'frustrations' of

\footnotetext{
${ }^{23}$ Jimenez, Ibid., 335-336; for a more detailed account on this see: Jimenez, ibid esp. « $4^{\mathrm{e}}$ partie: Les tournants du $\mathrm{XX}^{\mathrm{e}}$ siècle », 1 . Les tournants politiques de l'esthétique, 333-396, and 2. Les tournants culturels de l'esthétique, 397-432.

${ }^{24}$ Benjamin, Ibid., 44-56.

${ }^{25}$ Horkheimer and Adorno, Ibid., 1947/1991, 141-145.

26 Jürgen Habermas, The Theory of Communicative Action. Reason and the Rationalization of Society, transl. Th. McCarthy, Boston: Beacon , 1984.
} 
everyday life; the media are systems of language, boosters of verbal communication eliminating hindrances of both time and space. By increasing the frequency of oral transactions, the media allows for intersubjective understanding and comprehension independently of commercial preconditions; on the contrary, they would actually transmit aesthetic stimuli and experiences to wider audiences and, consequently they maintain the promesse $d u$ bonheur embedded in artwork, the notion of happiness (Glück), so endearing to Adorno. ${ }^{27}$ In other words, Habermas doesn't accept that the process of commodification radically compromises the relative autonomy of the aesthetic sphere.

To the cynicism of instrumental reason that results (according to Horkheimer and Adorno ${ }^{28}$ in bureaucracy and obscurantism, Habermas ${ }^{29}$ juxtaposes his 'communicative reason', a kind of rationality established on the verbal analysis of the issues, on individuals' sharing and interaction. Habermas' theory of communicative action provides a new theory for mediation and conflict resolution in general. Hence Habermas stands for the possibility of aesthetics, in the long run, acting upon other forms of rationality and eventually affecting culture and everyday life. ${ }^{30}$ The modern cultural system has eliminated the previous antagonism between an elitist bourgeois art and a mass culture that addresses a wider public audience, since it's governed by the utilitarian principle of profitability; it distributes to the greatest possible number of recipients the maximum of cultural goods, and this means that it may satisfy their desires and passions. ${ }^{31}$ A commercialized art-world and the system of mass media can still offer emancipatory possibilities.

\footnotetext{
${ }^{27}$ Adorno, Ibid.

${ }^{28}$ Horkheimer and Adorno, Ibid.

${ }^{29}$ Habermas, Ibid.

30 Jürgen Habermas, "Modernity - An incomplete Project", in: The AntiAesthetic. Essays on Postmodern Culture, Foster, Hal, (ed.) Port Townsend: Bay Press, 1983, 3-15; Jürgen Habermas, The Philosophical Discourse of Modernity: Twelve Lectures, trans. F. Lawrence, Cambridge, Mass.: MIT Press, 1987.

${ }^{31}$ Jimenez, Ibid., 420.
} 


\section{ARTISTIC CREATION IN THE ERA OF MASS MEDIA, WEB AND DIGITAL CULTURE}

With digital and other new technologies, the expressive and stylistic possibilities of the artwork are being expanded and developed, and these artworks, in turn, are enriched with a new aesthetic and ethical content. The process suggests a kind of technological determinism whereby new techniques for generating and distributing artworks yields radically new possibilities for style. ${ }^{32}$ Here, we consider John Walker's approach to art history as going further than a mere descriptive presentation of styles, artists' biographies and artworks. Specifically, Walker's theory ${ }^{33}$ claims that there are various parameters affecting the interaction between art and mass communication, i.e. significant changes in artists' social situation and the factors that determine these changes; the intermediate systems for presentation, projection, promotion and legitimization of the artworks and their creators, such as museums and galleries; the official institutions of artistic education and the mechanisms forming hierarchy and authority relations in the area of visual arts; the art market, their audience, their social, political and financial functions. ${ }^{34}$ From this position Walker offers a comprehensive account of belief formation concerning the autonomy of the artwork through the essential contributions of museums, educational institutes and disciplines like art history and criticism. Furthermore, he combines that specific account with the way mass communication systems (especially cinema and advertising) reproduce and enhance the general sense that artworks are due to exceptionally talented and ingenious persons; this stereotype

\footnotetext{
${ }^{32}$ Kostas Theologou, "Technology vis-à-vis the style of the representation: the necessity of the relation between art and technological application", in: Philosophy, Art and Technology, [in Greek] Boudouris, K. (ed.) Athens: Ionia, 2001, 57-70.

${ }^{33}$ Walker, Ibid.

34 Alexandros Baltzis, "John Walker's Analysis: Pre-modern Production of Meaning and Mass Communication", in: Art in the Age of Mass Media, John A. Walker, transl. [in Greek] H. Papavassiliou, P. Fylaktaki, Thessaloniki: University Studio Press, 2010, 15.
} 
obscures the multiple parameters that decisively effect art creation, and of course, its traditional position of social distinction and excellence. ${ }^{35}$

According to Habermas, the distinction of the three spheres (Science-Ethics-Art) entails a rather wide gap between the specialists of each sphere and their corresponding audiences. Cultural rationalization results in an impoverishment of the experienced world (Lebenswelt) whose traditional standing has been undervalued. ${ }^{36}$ All three spheres of specialized knowledge should be simultaneously accessible, but such a task seems beyond reach or at least very idealistic. ${ }^{37}$ And yet the shifting status of the artist and the avant-garde dictum that "anything can be an artwork" suggest the possibility that the art sphere is capable of expanding its scope, albeit at the cost of compromising its relative autonomy. If anything can be an artwork, perhaps then anyone can be an artist.

Art and communication in modern mass culture and society have a complicated and multifaceted relationship, suggesting the need for theory of mass communication, art history and art criticism, aesthetics, sociology of arts and mass media, cultural and visual studies, and even the semiotics of visual arts. We perceive art production as a social construction encompassing more than one single individual. ${ }^{38}$ The gradual establishment of postmodern stylistic and cultural pluralism ignited both positive and negative reactions; among the positive ones, acknowledgement of cultural variety and freedom of options contrasted with the uniformity of totalitarian regimes; among the negative ones, postmodernism revealed a decadent and divided society having lost its faith in the 'great narrations of progress and in the promising benefits of science and technology. ${ }^{39}$

\footnotetext{
${ }^{35}$ Baltzis, Ibid., 16.

${ }^{36}$ Habermas, 1987, Ibid.

${ }^{37}$ Habermas, 1983, Ibid., 8-10.

${ }^{38}$ Paul DiMaggio and Walter W. Powell, "The Iron Cage Revisited: Institutional Isomorphism and Collective Rationality in Organizational Fields", American Sociological Review 48, 1983, 147-160.

${ }^{39}$ Walker, Ibid., 197.
} 
The great universal dramas of human existence are all enacted upon local stages, after all. The digital highways of international communication networks ended up in a non-democratic corporate culture which disregards the needs of the unprivileged population. ${ }^{40}$ Artists should encourage 'local narrations' since they resonate with all oppressed and marginalized voices. Communities are no longer local to a geographical area; they are bound by their common interests. ${ }^{41}$
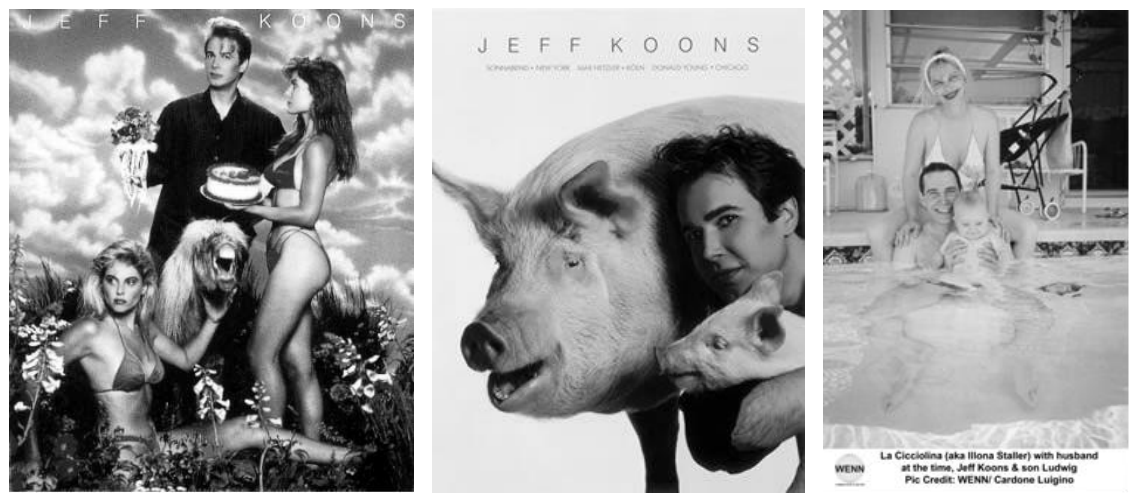

The advertising of visual arts is rarely shown on television spots; it mostly appears in special art magazines and journals, brochures and posters. The phenomenon of outdoor art advertising is related to the 1980s artistic work of Simon Linke (b. 1958 in Benalla, Australia) and Jeff Koons (b. 1955 in Pennsylvania, USA). Although most artists despise advertising as an applied art, those who exhibit in art-rooms and

40 Digital Highways was a large installation work (1991) produced as collaboration between Canadian artists Karl Berverage \& Carole Conde and British artists Peter Dunn \& Loraine Leeson. For further details at: http://www.arteofchange.com/sites/default/files/ArticleArchive/DigitalHighwaysLN_AND92.pd $\mathrm{f}$ (accessed on May 24, 2014).

${ }^{41}$ Peter Dunn, "Digital Highways, Local Narratives", AND: Journal of Art and Art Education, 27, 1992, 4-5, available at: http://static.and.org.uk/static/pdfs/No\%2027.pdf (Accessed May 24, 2014); Walker, Ibid., 200. 
public galleries are extremely depended on this 'art' due to publicity. ${ }^{42}$ Following Warhol, Koons specifically realized that his self-promotion is a creative opportunity. He invented, thus, coloured posters of himself and semi-naked models and animals; these images surely attracted attention of readers and brought art magazines closer to the layout patterns of mass culture magazines. As part of his attempt he married Italian porn-star Ilona Staller (a.k.a. Cicciolina).

Previously mentioned British artists Peter Dunn and Loraine Leeson presented their project about London Docklands (1982-83) in a poster series, including:
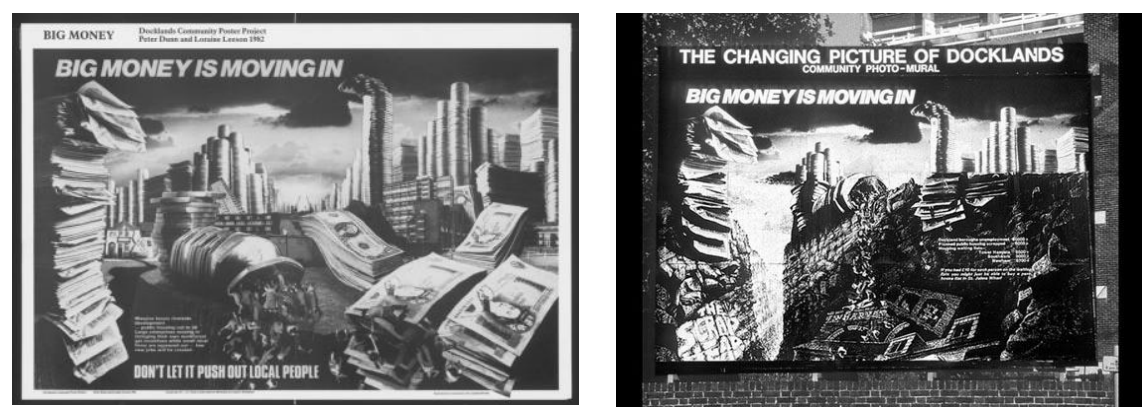

http://collections.vam.ac.uk/item/O1193211/big-money-is-moving-in-poster-dunn-peter/ accessed on May 24, 2014

Another artist, Irish Les Levine (b. Dublin, 1935) who works in New York, claims he coined the terms 'media sculpture' and 'media art'.

“...mass media is my material... I want to shape media the way others shape matter...I am into exploiting my expressive means in order to bring about change and comprehend our environment...if media changes people then people ought to change media ....43

\footnotetext{
${ }^{42}$ Walker, ibid, 248. And see Frazer Ward, "The Haunted Museum: Institutional Critique and Publicity", in October 73 (Summer 1995): 71-89

${ }^{43}$ Les Levine's claim mentioned in: Colin Naylor (ed.) Contemporary Artists. Chicago: St. James Press, ${ }^{3} 1989$, 554-556.
} 
Levine's concept of art resonates with the end of art concept introduced by Hegel. To interrogate the division between commercial and fine art is to disrupt the traditionally high status of the "work of art."44 That interrogation was introduced by Duchamp and taken up by Warhol, Rauschenberg, Levine, Koons, and others who embraced images from pop culture and advertising. Levine emphasized the ephemeral nature of the artwork, its way of being stuck in its milieu and prone to lapse into irrelevance. When that happens, the work ceases to be a live artwork and becomes a mere document. "Levine contemplated the purpose of art, and came to the conclusion that its function was to raise consciousness and communicate ideas. Once that process was complete, art ceased to be art, and instead became "a historical, exotic object." 45

When the artwork loses relevance, it ceases to be an artwork at all and becomes a "thing of the past," as Hegel said. The notion of the "end of art," then, connects the question of art's definition with the question of the fine art/commercial art distinction. These questions defined both the emergence of contemporary art and the development of philosophical aesthetics, with Arthur Danto using Warhol's "Brillo Box" as an interpretive key to Hegel's idea. ${ }^{46}$

${ }^{44}$ See Karen Coleman, "Habermas and Art: Beyond Distinction" in American Journal of Cultural Sociology (June, 2016) Vol. 4, No. 2 pp. 157-195, which reads MOMA's "High and Low: Modern Art and Popular Culture" exhibition (1990) through Habermas' theory.

${ }^{45}$ Sierra Bellows, "Disposable Art, Process Art, Media Art: Les Levine's RuleBreaking Work" National Gallery of Canada, 2017 https://www.gallery.ca/magazine/your-collection/disposable-art-process-artmedia-art-les-levines-rule-breaking-work

${ }^{46}$ See P. Winston Fettner, "Duchamp after Hegel: Exorcizing the End of Art" (2017) https://www.academia.edu/351430/Introduction_and_preparatory_remarks_for_ Duchamp_after_Hegel_Exorcizing_the_End_of_Art_and see fn. \# 59 and 60. 

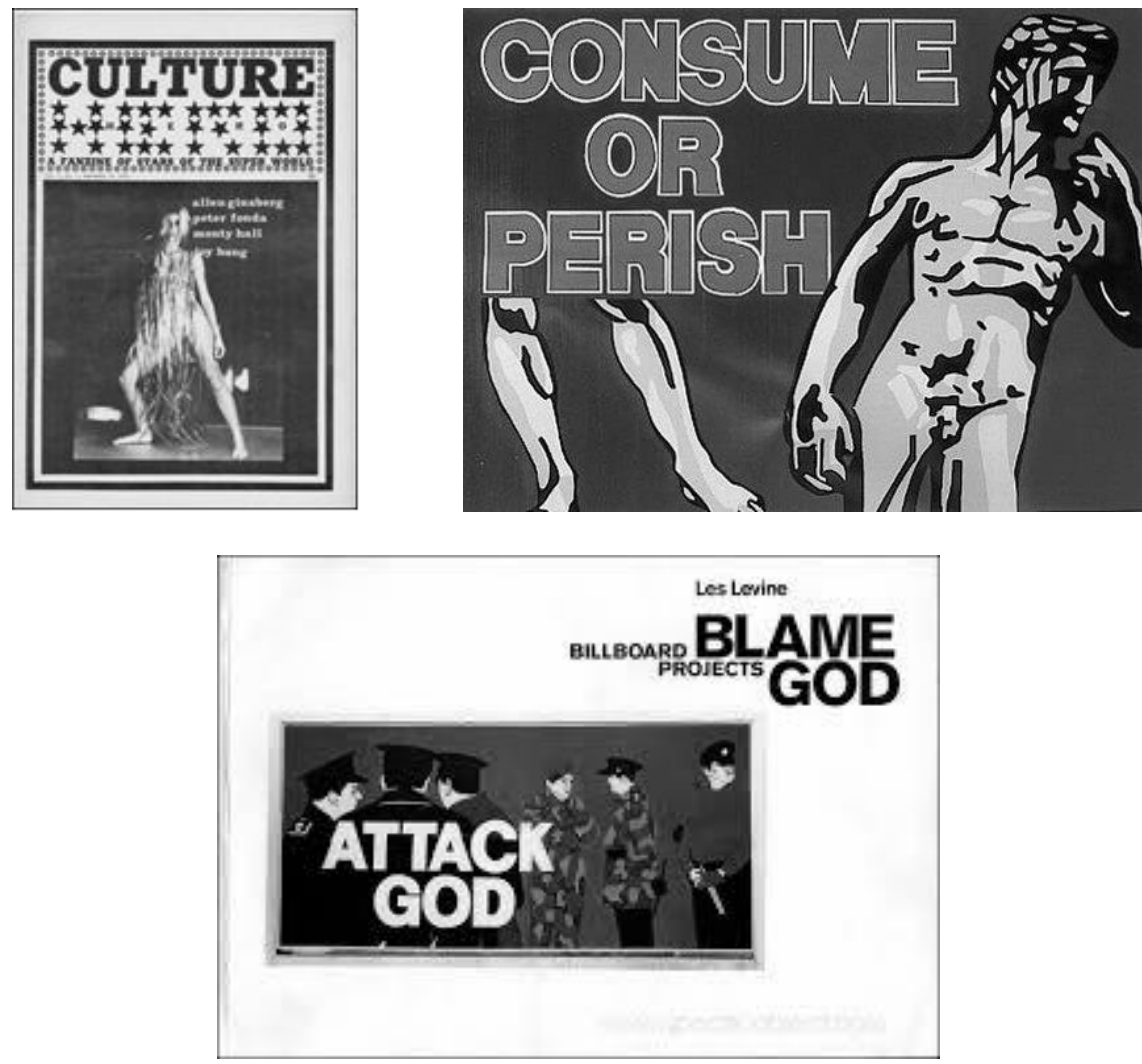

Les Levine's media-art provocative samples.

The Internet is among the most significant developments in the 1990s, together with web applications and the dot.com electronic business sphere. At the same time, 'digital' not merely became extremely popular, but was widely established as a new quasi-technological Paradigm, ${ }^{47}$ and dominates all aspects and activities of modern culture and behavior. All PC users with an internet access have access to enormous data banks, rapid and direct global communication, and exchange of mails, messages, images and videos. ${ }^{48}$ E-mail tools enhanced

47 All technological applications facilitated anyone with a PC, appropriate software and a digital camera to 'create' an artwork, an artifact or something alike.

${ }^{48}$ Walker, Ibid., 351-2. 
both the rapidity and the range of possibilities of the distribution of mail art, also known as post art and correspondence art. ${ }^{49}$

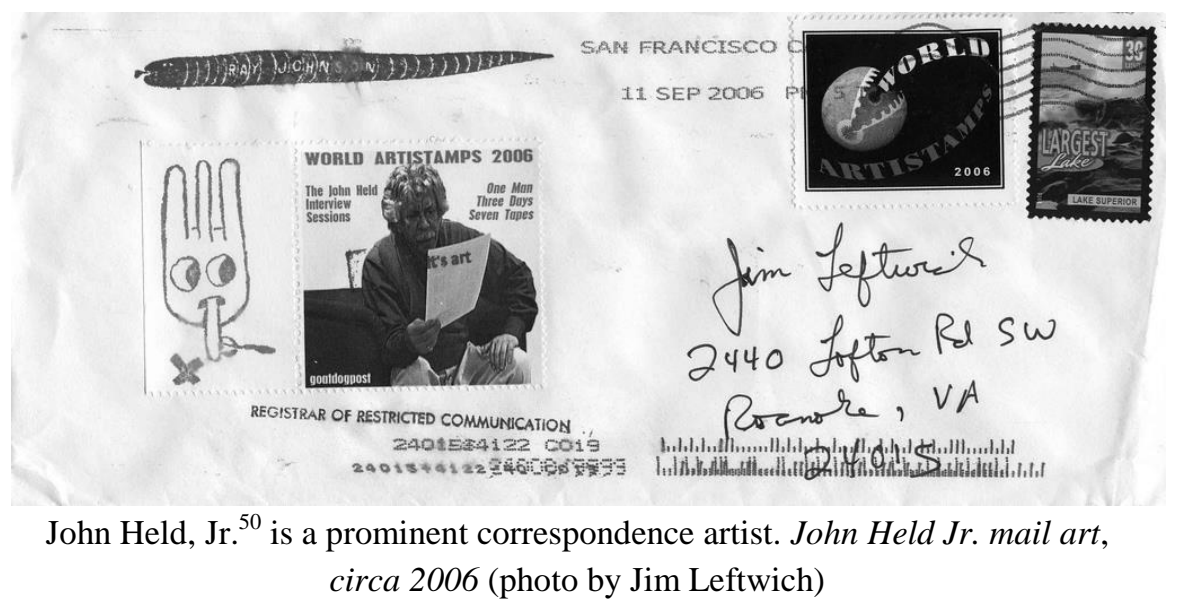

The concept of correspondence art contains all marginal forms of visual art that can be circulated by mail (cards, artistic stamps, photocopies etc.); it refers to the mode of transmission and not to the techniques of their making. ${ }^{51}$ By prioritizing the idea expressed by a work of art instead of its technical form or creation as an accomplished product, mail-art is well considered as conceptual art $^{52}$ or as performance art. $^{53}$

49 Mail art periodicals can be found at: http://merzmail.files.wordpress.com/2011/01/the_museum_of_modern_art_librar y.pdf (Accessed May 24, 2014).

50 More info details at: http://www.aaa.si.edu/collections/john-held-papersrelating-to-mail-art-6273/more (Accessed May 24, 2014).

${ }^{51}$ Some pioneering forms of such 'art-products' may be tracked back to Marcel Duchamp (1912, 1917) and the Italian futurists (1909), but as a world movement it's related to the quasi-dadaist fluxus group of artists (1959-1978), a loosely organized group of artists that spanned the globe, but with an especially strong presence in New York.

52 Herbert Read, Dictionary of Arts and Artists, London: Thames and Hudson, 1984 [in Greek transl. A. Pappas, Athens: Ypodomi, 1986, 82; Roberta Smith, "Conceptual Art", in: Concepts of Modern Art. From Fauvism to Postmodernism, Nikos Stangos, (ed.) Athens: MIET [in Greek], 2005, 355-375. 
Along the same lines as John Held Jr., Joseph Beuys (19211986), a German conceptual artist and politician, coined the term social sculpture to illustrate his idea of art's potential to transform society. As an artwork it includes human activity that strives to structure and shape society or the environment. The central idea of a social sculpture is an artist who creates structures in public using language, thought, action, and object. ${ }^{54}$ Conceptual art has been associated with Body Art, which is practically an action, a performance, in which the artist exposes his own body, in a quasi-masochist mode, to various tests and even hardships, depicts that exposure, thereby documenting the art-process, and finally presents it to the audience. The fluxus performances e.g. by Joseph Beuys and Yves Klein in the 1960s used their own bodies as active material for their performances as below:
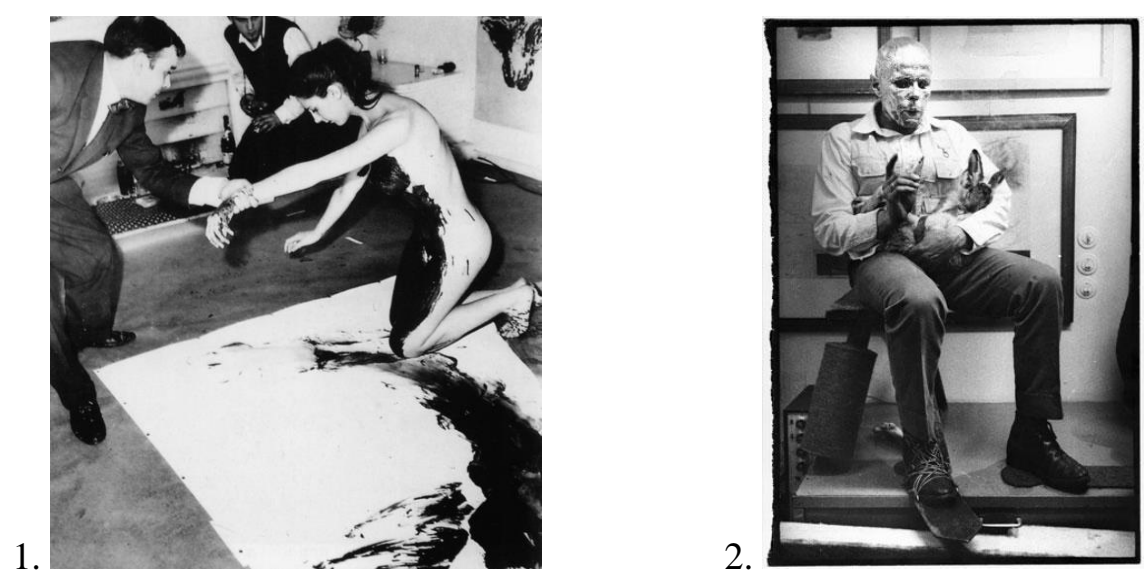

In pic. 1 Yves Klein (1960) Anthropométrie à Campagne-Première, Galerie Internationale d'Art Contemporain, Paris and in pic. 2 Joseph Beuys (1965), How to Explain Pictures to a Dead Hare, Gallery Schmela Dusseldorf.

Read, 1986: $82 \cdot$ Smith, 2005: 355-357

53 RoseLee Goldberg, "Performance: a Hidden History", in The Art of Performance. A Critical Anthology, Greg. Battock \& Nickas, Rob. (eds.) /ubueditions, 2010, 22-55.

${ }^{54}$ Caroline Tisdall, Art into Society, Society into Art, London: ICA, 1974, 48. 
In 1964 another action took place in Paris and New York, a joint performance by American Carolee Scheemann (b. 1939) and French theoretician Jean-Jacques Lebel (b. 1936) under the title Meat Joy (a double entendre for eating meat and meeting with joy); the participant artists were semi-naked men and women who stripped each other and fell on the floor among pieces of raw meat and fish, chicken and sausage (pic. 1). They covered each other with animal blood and red colour, squeezed their bodies on paper, and threw pieces of meat against each other, while kissing, swirling until they dropped from fatigue. ${ }^{55}$ Critics of the time related the action to Bacchic rituals and the Dionysian mysteries of Ancient Greece. Such rituals, involving slaughtered animals, were common in Orgien Mysterien Theater, founded by Hermann Nitsch (b. 1938). His notorious $80^{\text {th }}$ action (pic. 2) took place in 1984; on a superficial reading of the action, their repeated violent gestures (suggestive of self-mutilation, animal sacrifice, sadomasochism, etc.) appear to signal obvious nihilistic undertones; upon closer consideration, they seem to drive at something deeper and more complex by conflating the power dynamics involved in art, sex, religion, and politics. ${ }^{56}$

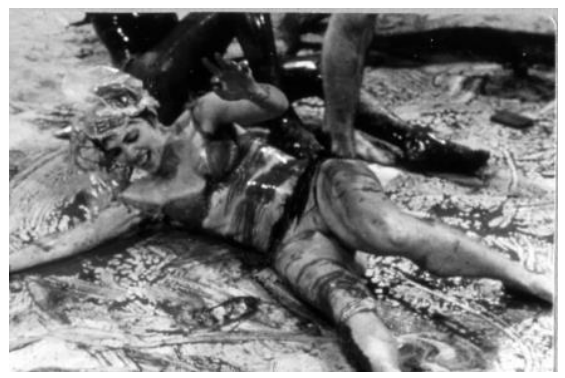

1.

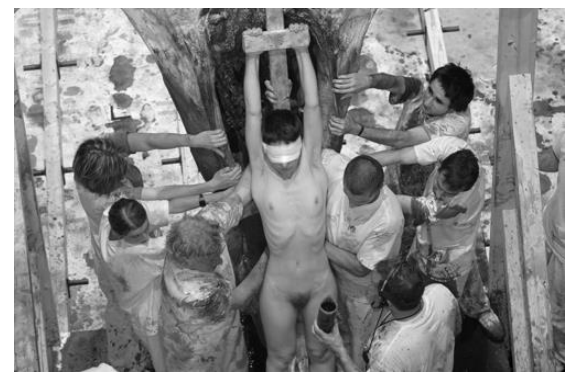

2.

In any case, the art community soon realized the benefits from being on the web; there are specific sites of individual artists, virtual archives, artistic institutions and associations, art auctions, galleries and

55 Melita Emmanouil, "Ch. 4. The Science and Technology Contribution", in: History of Art since 1945 in five chapters [in Greek], Athens: Kapon, 2013, 168. ${ }^{56}$ Ibid., 169. 
entire museum collections, e-magazines of art etc. available online. These new conditions resulted in new terminology - net-art, online art - while encouraging the incorporation of new professions, e.g. web designers; they also allow for a critical interference by the artists. ${ }^{57}$ Conceptual art benefits greatly from the internet, because (unlike the case of traditional painting and sculpture) there's no need to be in the actual presence of the artwork to fully appreciate and interpret its significance. The images and explanations available online communicate the concept behind the work, and we've grasped it. At the same time, the traditional arts also benefit from the internet as an invitation to visit and study them. And now, there are artists who focus on the nature of internet communication.

Cypriot-Australian and somehow ambiguous artist Stelarc (Stelios Arcadiou, 1946) ${ }^{58}$ is suggested as a specific case of redefining art as a communication experience in the new digital era. ${ }^{59}$ Stelarc claims that the Internet is not merely a means of transmitting information but also affects the physical action between bodies. He has always been uneasy about the artist as simply a craftsperson who simply makes or produces cultural artifacts that are considered beautiful or sensitive or whatever. What's more intriguing for Stelarc is the artist who works with ideas, who uses their art as a means of exploring the personal and the public, and who tries to get a sense of what it means to exist in the world. $\mathrm{He}$ is much happier if the artist is seen as a poet or a philosopher than as a

${ }^{57}$ Walker, Ibid., 353.

${ }^{58}$ In 1972 the man born Stelios Arcadiou took on a new name. He refashioned himself as the artist Stelarc, whose work often explores what he calls "alternate anatomical architectures." He's probed his body with cameras, creating films that lay bare the visceral inner workings of his stomach, lungs, and colon. He's deprived his body, spending five days with his eyes and lips sewn shut. He's manipulated his body with electricity, connecting electrodes to his muscles and letting others move him like a drunken, flailing robot. And he's augmented his body through exoskeletons and prostheses, including a mechanical third hand. In: http://www.theverge.com/2012/9/14/3261078/meat-metal-and-code-stelarcsalternate-anatomical-architectures (accessed April 24, 2014). A rather informative video on his work may be found at: http://motherboard.vice.com/read/from-the-motherboard-vault-stelarc--2

(accessed April 25, 2014).

${ }^{59}$ Theologou, Ibid., 63-66, 70. 
craftsperson. Stelarc's performances using mechanical and bio-prostheses are not as physically or psychologically hard on an audience. ${ }^{60}$ They don't involve pain or mutilation and have more in common with live theatre with a science-fiction theme.

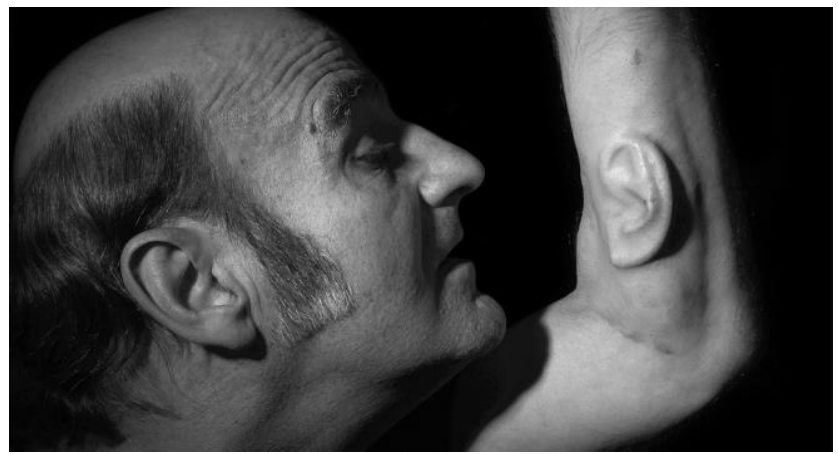

1.

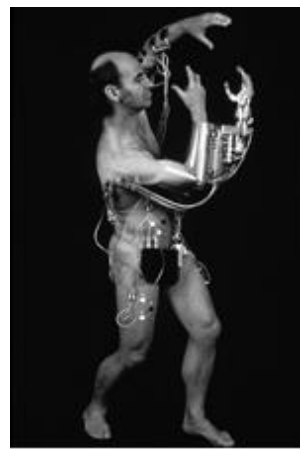

2.

Stelarc's work continues to re-examine the possibilities of the body as a site for experimentation. 1. His 1972 project, Ear on Arm, is a surgically constructed ear grown from cells and attached to, well, his arm. The ear will eventually be connected to the internet, allowing anyone around the world to listen through it. 2. The amplified body (1985) available at: http://cec.sonus.ca/econtact/14_2/ stelarc_gallery.html

Behind the shocking image of a real ear on Stelarc's arm is the possibility that internet technology has become part of us, our smartphones an appendage for communication in a public sphere undergoing a structural transformation; that suggestion is at odds with Habermas' controversial sense that the internet itself does not necessarily constitute a development of the public sphere at all. "The classical public sphere stemmed from the fact that the attention of an anonymous public was 'concentrated' on a few politically important questions that had to be

\footnotetext{
${ }^{60}$ Audiences find his work controversial and only a well-informed audience cognizant of contemporary art practices and his ideas in relation to contemporary science and medical practice will fully appreciate Stelarc's art-making. More at: http://www.curriculumsupport.education.nsw.gov.au/multicultural_art/artists/con struct_ourselves/co_art13_stelarc.html (accessed April 24, 2014).
} 
regulated. This is what the web does not know how to produce. On the contrary, the web actually distracts and dispels." ${ }^{\prime 61}$ Nevertheless, Stelarc's work illustrates how the system has entered the lifeworld in the form of advanced technology, giving shape to a fundamental source of anxiety and a question of fundamental importance to the global public. The images he creates are in that sense a revisiting of high modernism rather than a postmodern irony; Stelarc is too serious to be a postmodernist. We see here that current developments require revising Habermas' theory to accommodate internet communication: "the ideal public sphere he described - a bourgeois public sphere dominated by broadcast media should not be taken as the model for the formation of public opinion in 21 st century democracies." ${ }^{62}$ So Stelarc's artworks, both in their subjectmatter and because of their primary mode of distribution-digital photos available on the Worldwide Web-call for retaining Habermas' theories, but in revised and updated form.

\section{FROM THE DIGITAL, WEB AND MEDIA ART APPLICATIONS TO THE NOVEL EXPERIENCE: ART REVISITED}

Is there a decline of art? Is the artworld art somehow trapped in a cycle of decadence? Does art demand a new definition and a contemporary reconceptualization of its role? It is extremely important to our artistic, societal and political health that we find our way through

\footnotetext{
${ }^{61}$ Jürgen Habermas interviewed by Markus Schwering, "Internet and Public Sphere

What the Web Can't Do" in ResetDOC (Thursday, 24 July 2014) http://www.resetdoc.org/story/00000022437 ; see also R. Stuart Geiger, "Does Habermas Understand the Internet? The Algorithmic Construction of the Blogo/Public Sphere" in Gnovis: A Journal of Communication, Culture, and Technology (Vol. 10, No. 1) Fall, 2009 http://stuartgeiger.com/papers/gnovishabermas-blogopublic-sphere.pdf

${ }^{62}$ Howard Rheingold, "Habermas blows off question about the Internet and the Public Sphere" in Smartmobs (November 5th, 2007) http://www.smartmobs.com/2007/11/05/habermas-blows-off-question-about-theinternet-and-the-public-sphere/
} 
abstract trivialities and sterile ideological impasses toward an art of substantial significance based on contemporary pragmatism that draws from cultural reality and creates symbols expressive of and supportive of humanity in this crucial period of obscurantism and spiritual inertia. In the puzzling and complex transition from modernism to postmodernism, the new terrain of a rather perceptible fact is being realized by both artcreators and their audience, and this clearly concerns an exploration of the limits of art. The attempts to overturn established conventions are but mere routines. Innovation in art, though desirable, seems impossible as long as we keep considering that anything as art.

Modernity is a qualitative, not merely a historical era; in any other approach the periodization proves problematic. Adorno would have us understand modernity as the rejection of the false rationality, harmony, and coherence of Enlightenment thinking, art, and music. In this paper (part 2, above) we discussed the complexity of modern aesthetics and its critique due to the inescapable correlation between art-culture and society; the complexity of contemporary art could be further clarified by these critical approaches:

a) Friedrich Hegel claims that art seeks to express the transcendent in the physical, and finally comes to an end in favor of philosophy. "Art, for Hegel, also gives expression to spirit's understanding of itself. It differs from philosophy and religion, however, by expressing spirit's self-understanding not in pure concepts, or in the images of faith, but in and through objects that have been specifically made for this purpose by human beings. Such objects - conjured out of stone, wood, color, sound or words - render the freedom of spirit visible or audible to an audience". ${ }^{6}$

b) Suzi Gablik wonders whether modernism has failed (1985). ${ }^{64}$ By 'failed' does she simply indicate the sense of coming to an end, or

63 Stephen Houlgate, "Hegel's Aesthetics", in The Stanford Encyclopedia of Philosophy, Edward N. Zalta, (ed.) 2014, available at http://plato.stanford.edu/archives/spr2014/entries/hegel-aesthetics (accessed on May, 25, 2014).

${ }^{64}$ Suzi Gablik, Has Modernism Failed?, London: Thames \& Hudson, 1985. 
does she mean, like Habermas (1983), ${ }^{65}$ that modernism failed to accomplish something? The presupposition of the latter is that modernism had goals which it failed to achieve; after all modernism overthrew tradition, and we must recover it if art is to survive. And is it now possible to recover a modernist project within the environment of irony, self-referentiality, and satire that dominate today's artworld? Can the aesthetic sphere resist having its autonomy compromised by the process of commodification?

c) Arthur Danto, like Hegel, argues that art history has come to an end and that art seeks its own essence: art history ends once art puts the proper question to philosophy i.e., what makes something art if it looks just like a piece of non-art? ${ }^{66} \mathrm{~d}$ ) Larry Shiner (2001) challenges our conventional understandings of art and asks us to reconsider its history entirely, arguing that the category of fine art is a modern invention - that the lines drawn between art and craft (in the $19^{\text {th }} \mathrm{c}$.) resulted from key social transformations in Europe during the long eighteenth century. ${ }^{67}$

The fact is that art is being transformed, like any other live and vivid organism. Art develops new styles of expression and evolves to survive in a culture where technology prevails; in other words art may suffer a form of technological determinism, which some critics and art historians are reluctant to acknowledge. Art transforms in interactions, techniques, styles, and attracts our attention and our care; it's not only a matter of aesthetics or philosophy, but also the ethics of expanding our criticism and research to accommodate all of these new phenomena. It seems inevitable to redefine art - this is a task for philosophers and art critics; it's equally inescapable for the audience to adjust to novel cultural experiences in a world where communication and media prevail. The internet was the boundary for the postmodern, and the 'digital' stretches social and cultural creativity to new artistic frontiers!

\footnotetext{
${ }^{65}$ Habermas, 1983, Ibid.

66 Arthur Danto, "The End of Art: A Philosophical Defense", History and Theory, 37, 4, 1998: 131-2.

${ }^{67}$ Larry Shiner, The Invention of Art. A Cultural History, Chicago: Chicago U.P. 2001.
} 


\section{REFERENCES}

Adorno, Theodor W., Minima Moralia, Reflexionen aus dem beschädigten Leben. Frankfurt am Main: Suhrkamp 1951. [Minima Moralia, Reflexions from Damaged Life, transl. D. Redmond, 2005, also available at: http://monkeybear.info/MinimaMoralia_Full.pdf (accessed May 25, 2014).

Adorno, Theodor W., Asthetische Theorie, Frankfurt am Main: Suhrkamp, 1970 [Aesthetic Theory. transl. R. Hulot-Kentor, New York-London: Continuum, 1997]

Adorrno Theodor W., "Culture Industry reconsidered", in The Culture Industry. Selected essays on mass culture, J. M. Berstein (ed.), 98-106.London and N.Y.: Routledge, 1991.

Arantes, Otilia B. F. and Paulo Eduardo, Arantes, "The Neo-Enlightenment Aesthetics of Jürgen Habermas", transl. G. Hovarth \& M. C. de Paula Soares, Cultural Critique, 49: (2001), 43-57, also at http://muse.jhu.edu/login?auth=0\&type=summary\&url=/journals/cultur al_critique/v049/49.1arantes.html. (acc. May 25. 2015)

Baltzis, Alexandros, "John Walker's Analysis: Pre-modern Production of Meaning and Mass Communication", in Art in the Age of Mass Media, Walker, John A., transl. [in Greek] H. Papavassiliou, P. Fylaktaki Thessaloniki: University Studio Press, 2010, 11-27.

Baudrillard, Jean, "The Ecstasy of Communication”, in: Foster, Hal, (ed.) 1983. The Anti-Aesthetic. Essays on Postmodern Culture, Port Townsend: Bay Press, 1983, 126-134.

Benjamin, Walter, Das Kunstwerk im Zeitalter seiner technischen Reproduzierbarkeit, 1936, [L' oeuvre d'art à l'époque de sa reproduction mécanisée, transl. P: Klossowski, at: http://ia600805.us.archive.org/2/items/ZeitschriftFrSozialforschung5.Jg /ZeitschriftFrSozialforschung51936.pdf, Paris: Librairie Félix Alcan, 1937, 40-68 (accessed May 25, 2014).

Blumer, Herbert, Symbolic Interactionism: Perspective and Method. Englewood Cliffs, NJ: Prentice-Hall, 1969.

Blumer, Herbert, "Social Problems as Collective Behavior", Social Problems 18, (1971). 298-306.

Danto, Arthur, "The End of Art: A Philosophical Defense", History and Theory, 37, 4, (1998). 127-143. 
DiMaggio, Paul and Walter W. Powell, "The Iron Cage Revisited: Institutional Isomorphism and Collective Rationality in Organizational Fields", American Sociological Review 48, (1983). 147-160.

Dunn, Peter, "Digital Highways, Local Narratives", AND: Journal of Art and Art Education, 27, (1992). 4-5, available at: http://static.and.org.uk/static/pdfs/No\%2027.pdf (Accessed May 24, 2014).

Emmanouil, Melita. "Ch. 4. The Science and Technology Contribution", [in Greek] in History of Art since 1945 in five chapters, by M. Emmanouil, 142-175, Athens: Kapon, 2013.

Jimenez, Marc, Qu'est-ce que l'esthétique, Paris: Gallimard, 1997.

Gablik, Suzi, Has Modernism Failed?, London: Thames \& Hudson, 1985.

Goldberg, RoseLee, "Performance: a Hidden History", in: The Art of Performance. A Critical Anthology edited by Greg Battock \& Nickas, Rob. 22-55, / ubueditions, 2010 (accessed May 25, 2014).

Habermas, Jürgen, 1983. "Modernity- An incomplete Project", in: The AntiAesthetic. Essays on Postmodern Culture, edited by Foster, Hal, 3-15. Port Townsend: Bay Press, 1983.

Habermas, Jürgen, The Theory of Communicative Action. Reason and the Rationalization of Society, transl. Th. McCarthy, Boston: Beacon, 1984.

Habermas, Jürgen, The Philosophical Discourse of Modernity: Twelve Lectures, trans. F. Lawrence, Cambridge, Mass.: MIT Press, 1987.

Horkheimer, Max, Theodor W. Adorno, „Kulturindustrie, Aufklärung als Massenbetrug“, in: Dialektik der Aufklärung. Philosophische Fragmente, 148-196. Frankfurt am Main: Fischer, 1947/2012.

Houlgate, Stephen, 2014. "Hegel's Aesthetics", in The Stanford Encyclopedia of Philosophy, edited by Zalta, Edward N., available at the site (accessed May 25, 2014): http://plato.stanford.edu/archives/spr2014/entries/hegelaesthetics.

Leavis, Frank Raymond, Mass Civilization and Minority Culture. Cambridge: CUP, 1930.

Leavis, Frank Raymond, Denys Thompson, Culture and Environment: The Training of Critical Awareness, London: Chatto \& Windus, 1933.

Leavis, Frank Raymond, The Great Tradition George Eliot, Henry James, Joseph Conrad. London: Chatto \& Windus, 1948.

Lewis, Wyndham, Men without Art, London: Cassell, 1934.

Lewis, Wyndham, The Human Age. Book 2: Monstre Gai. Book 3: Malign Fiesta (ill. M. Ayrton), London: Methuen, 1955. 
Lyotard, Jean-François, La condition postmoderne: rapport sur le savoir, Paris : Minuit, 1979.

Marcuse, Herbert, "The Affirmative Character of Culture", in: Herbert Marcuse: Art and Liberation, vol. 4, edited by Douglas Kellner, 82-112, London and N.Y.: Routledge, 1932/2007.

Naylor, Colin (ed.), Contemporary Artists. Chicago: St. James Press, ${ }^{3} 1989$.

Ortega y Gasset, José, The Dehumanization of Art, and Other Writings on Art and Culture. Garden City, N.Y.: Doubleday Anchor Books, 1956.

Ortega y Gasset, José,. The Revolt of the Masses, transl. authorized, London: Allen \& Unwin, 1961.

Park, Robert Ezra, "Cultural Conflict and the Marginal Man" (Introduction), in The Marginal Man. A Study in Personality and Culture Conflict, xiiixviii, edited by Everett V. Stonequist, New York: Charles Scribner's Sons, 1937.

Park, Robert Ezra, C. W. M Hart, Talcott Parsons et al. Essays in Sociology. Toronto: University of Toronto Press, 1940.

Park, Robert Ezra, Race and Culture, Glencoe Ill: The Free Press, 1950.

Read, Herbert, Dictionary of Arts and Artists, London: Thames and Hudson, 1984 [in Greek transl. A. Pappas, Athens: Ypodomi, 1986.

Rapti, Youli, "The end of autonomy in modern art", in Humanities and Social Sciences in NTUA: fertile ramifications, [in Greek] edited by I. Milios K. Theologou (eds.) 271-280, Athens: NTUA publications, 2011.

Shiner, Larry, The Invention of Art. A Cultural History, Chicago: Chicago U.P., 2001.

Smith, Roberta, "Conceptual Art", in Concepts of Modern Art. From Fauvism to Post-modernism, [in Greek], edited by Stangos, Nikos, 355-375 Athens: MIET, 2005.

Theologou, Kostas, "Technology vis-à-vis the style of the representation: the necessity of the relation between art and technological application", [in Greek], in Philosophy, Art and Technology, edited by Boudouris, K., 57-70 Athens: Ionia, 2011.

Tisdall, Caroline, Art into Society, Society into Art, London: ICA, 1974.

Walker, John A., Art in the Age of Mass Media, London: Pluto, 2001.

Williams, Raymond, Culture and Society 1780-1950, Garden City, NY: Doubleday Anchor Books, 1960.

Zuidervaart, Lambert, 2011. "Theodor W. Adorno", in The Stanford Encyclopedia of Philosophy, edited by Ed. N. Zalta, http://plato.stanford.edu/archives/win2011/entries/adorno/ (accessed May 24, 2014) 


\section{KOSTAS TEOLOGU}

Nacionalni tehnički univerzitet u Atini, Grčka

JULI RAPTI

Nacionalni tehnički univerzitet u Atini, Grčka

PITER FETNER

Univerzitet Džons Hopkins, Škola napednih međunarodnih studija,

Vašington D. C., SAD

JULI PAPAJOANU

Nacionalni tehnički univerzitet u Atini, Grčka

\section{UMETNOST I KOMUNIKACIJA KAO NOVO ISKUSTVO U MODERNOJ KULTURI}

Sažetak: U ovom radu raspravljamo o stranputicama u definisanju umetnosti u modernoj kulturi. Nedostatak kriterijuma i preispitani modernizam u tom su pogledu od ključnog značaja. Teorijski okvir našeg pristupa zasnovan je na radu mislilaca Frankfurtske škole (Maks Horkhajmer, Teodor Adorno, Valter Benjamin) i naravno Jirgena Habermasa. Ovaj teorijski aparat oslanja se i na savremena razmatranja sprovedena kod profesora Sorbone Marka Himeneza i kritičara umetnosti Džona A. Vokera. ${ }^{68}$ Rad raspravlja o tome da li, u kojim oblicima - i s kojom svrhom - lepe umetnosti mogu da prežive u dobu masmedija i u uslovima brze mrežne komunikacije. Rad polazi od kritičke uloge koju radikalna umetnost igra u današnjem podeljenom, ali još uvek globalizovanom svetu i u stalnim raspravama između visoke umetnosti i niske kulture, ali i reflektuje interakciju između umetnosti, medija i tehnologije.

Kao potporu našoj argumentaciji predlažemo umetnost tela (Body Art) i druge veb/digitalne i tehnološke primene u umetnosti, kao i sajber-umetnost koja se trenutno proizvodi za internet. Rad potvrđuje postojanje brojnih interakcija između umetnosti i kulture u postmodernom pluralističkom svetu i obraća se širokom spektru savremenih umetničkih dela kako bi ilustrovao i kritikovao teorijska stanovišta. Istinska proba teorije u estetici jeste njena primena na pojedinačne slučajeve. Kada teorija u takvoj primeni pokazuje ograničenja,

${ }^{68}$ Marc Jimenez, Qu'est-ce que l'esthétique, Paris: Gallimard, 1997; John A. Walker, Art in the Age of Mass Media, London: Pluto, 2001. 
stičemo indicije kakva se teorijska prilagođavanja ili inovacije traže kako bi se prilagodila današnjim delima.

Uvodni deo ogleda sveobuhvatno razmatra skorašnje rasprave o umetničkim delima, masovnoj kulturi i društvu, kao i o njihovom društvenofilozofskom značaju. Središnje raspravljanje upućuje na delo Valtera Benjamina i Jirgena Habermasa, koje je prikladnim komentarima propratio Mark Himenez; ${ }^{69}$ nakon istraživanja složenih odnosa između kulture i umetnosti kakvim se oni odražavaju u tom delu, argumentacija pruža prikaz političkog preokreta u estetici iz 1980-ih i objašnjava značaj novih komunikacionih tehnologija u modernoj kulturi. Naracija je ojačana specifičnim primerima umetničkih dela u eri mas-medija, veb i digitalne kulture i naglašava kako stilski pluralizam, tako i raznovrsnost parametara koji utiču na interakciju između umetnosti komunikacije mas-medijima. Rad zaključuju kritički uvidi i predlozi za dalje istraživanje.

Ključne reči: umetnost, tehnološke primene, masovna kultura, iskustvo

Primljeno: 20.8.2019. Prihvaćeno: 2.11.2019.

${ }^{69}$ Jimenez, Ibid. 